\title{
УДОСКОНАЛЕННЯ ПІДГОТОВКИ МАЙБУТНІХ ЛІКАРІВ В УНІВЕРСИТЕТАХ КИТАЮ
}

\begin{abstract}
У статті охарактеризовано наявні можливості та перспективи розвитку медичної освіти в Китаї, виокремлено проблеми, які нині потребують розв'язання на державному рівні для створення однієї з найкращих моделей підготовки лікарів у ХХІ столітті. Дослідженням виявлено, щчо в 2016 роиі урядом Китаю була схвалена амбіиійна нова національна політика «Здоровий Китай 2030», ключовою метою якої є поліпшення якості медичного обслуговування та підвищення професійності лікарів для надання медичних послуг. Ефективне впровадження урядової політики вимагає наявності великої кількості добре навчених лікарів. 3 метою збільшення кількості лікарів і вдосконалення підготовки фахівиів у галузі медицини університети Китаю акумулюють передовий світовий досвід інших країн світу. Встановлено, щуо в Китаї впроваджена стандартизована програма підготовки лікарів і післядипломної медичної освіти тривалістю три роки. Аналіз літератури з питань китайської медицчини та підготовки професійних лікарів у закладах вищэої освіти свідчить, щзо ЗВО в КНР готують майбутніх лікарів, розвиваючи їхні клінічні навички та аналітичне мислення, широко застосовуючи проблемне навчання, готуючи таким способом майбутніх лікарів до розв 'язання негайних і складних викликів у майбутній професійній діяльності.

У статті обтрунтовано роль, місце $і$ значення Китайської асоціації лікарів, яка проводить значну роботу для поліпшення державного медичного обслуговування, забезпечує керівництво для китайської медичної спільноти та проводить міжнародні тренінги з нормалізаџії навчання лікарів-резидентів Китаю, які сприяють удосконаленню підготовки фахівиів у галузі медицини в університетах країни. Аналіз наукових джерел показав, щуо підвищення ефективності китайської системи охорони здоров'я є ключовим для розв 'язання поточних проблем, наприклад поліпшення клінічних навичок китайських лікарів, зменшення непотрібного або повторюваного лабораторного або візуального обстеження тощзо. У статті розкрито методи навчання лікарів, які полягають у моделюванні реальних ситуацій, щзо значною мірою доповнює традиційне дидактичне навчання. Китайські дослідники довели, щзо успіх реформи вищої медичної освіти в КНР залежить від добре професійно освічених медичних працівників, які мають клінічну та етичну компетентність, необхідні для надання якісних лікарських послуг. У дослідженні описано та проаналізовано шляхи вдосконалення підготовки лікарів у Китаї.

Ключові слова: медична освіта в Китаї, підготовка майбутніх лікарів, якість підготовки лікарів, навчання впродовж життя, професійна компетентність лікаря, клінічні навички.
\end{abstract}

Oksana DUDINA, orcid.org/0000-0003-0405-5837

Candidate of Pedagogical Sciences, Lecturer at the Department of Languages and Humanities № 2 Donetsk National Medical University (Kropyvnytskiy, Ukraine) rexiff@ukr.net

\section{IMPROVEMENT OF TRAINING OF FUTURE DOCTORS IN CHINA UNIVERSITIES}

The article describes the existing opportunities and prospects for the development of medical education in China, highlights the problems that currently need to be addressed at the state level to create one of the best models of medical training in the $21^{\text {st }}$ century. The study found that the Chinese government approved an ambitious new national policy "Healthy China 2030", the key goal of which is to improve the quality of health care and improve the professionalism of doctors to provide medical services. Effective implementation of government policy requires a large number of well-trained doctors. In order to increase the number of doctors and improve the training of masters in medicine, Chinese universities are accumulating world best practices from other well-developed countries. It is established that a standardized program of training doctors and postgraduate medical education lasting three years has been introduced in China. An analysis of the literature about the training of professional physicians in Chinese higher education institutions shows that free medical education in CPR prepares future physicians by developing their clinical skills and analytical thinking, widely using problem-based learning, thus preparing future physicians to address immediate and complex challenges in the future professional activity. 
The article substantiates the role, place and importance of the Chinese Association of Physicians, which does significant work to improve public health care, provides guidance to the Chinese medical community, and conducts international training to normalize the training of Chinese resident physicians to improve university medical training on the mainland. An analysis of scientific sources has shown that improving the efficiency of the Chinese health care system is key to solving current problems, such as improving the clinical skills of Chinese doctors, reducing unnecessary or repetitive laboratory or visual examinations, and so on. The article reveals the methods of teaching doctors, which are to model real situations, which greatly complements the traditional didactic training. Chinese researchers have shown that the success of higher health education reform in China depends on well-trained health professionals who have the clinical and ethical competencies needed to provide quality medical services. The study describes and analyzes ways to improve the training of doctors in China.

Key words: medical education in China, training future doctors, quality of training doctors, lifelong learning, professional competence of doctor, clinical skills.

Постановка проблеми. Згідно з Глобальною статистикою фахівців у галузі охорони здоров'я та Всесвітньої організації охорони здоров'я, яка доповнює дані про країни, у 2010 році в Китаї було 1,8 лікарів на 1000 жителів, і ця кількість збільшується останніми роками; тоді як у 2010 році в Індії було 0,6 лікарів, у Південній Кореї - 2,0 лікаря, у Японії - 2,3 лікаря, у Канаді - 2,1 лікаря (Світовий банк, 2014). Статистика показує, що медична освіта в Китаї забезпечує країну висококваліфікованими лікарями. Швидка та ефективна реакція китайських лікарів на дослідження та лікування COVID-19 свідчить про те, що медична освіта в Китаї є на високому рівні.

Аналіз досліджень. Аналіз останніх досліджень і публікацій показав, що питанням удосконалення підготовки лікарів в університетах Китаю присвячено праці таких китайських учених, як: Йі-Сянг Дж. Ванг, Д. Лі, С. Ліан, Ц. Чень, М. Яо, Ч. Чі, М. Д. Феттерс та інші. Вдосконаленням і розвитком навчальних курсів для фахівців сімейної медицини в Китаї займалися такі дослідники, як Д. Ши, Х. Лу, Х. Ван, С. Бао, Л. Цянь та інші.

Систему вищої освіти в Китаї вивчали такі українські вчені, як: Є. Гобова, В. Мумладзе, Н. Мирончук, але вдосконалення підготовки лікарів у ЗВО КНР для України є не досить висвітленими в педагогічній вітчизняній науці. Важливим джерелом вивчення досвіду підготовки майбутніх лікарів у медичних університетах Китаю є праці китайських науковців-практиків Р. Мей, Г. Оце, Ч. Лі, Л. М. Розенфельд, Дж. Джон Велоксі і Ю. Лін.

Мета статті - визначити особливості підготовки лікарів в університетах Китаю.

Виклад основного матеріалу. Китайський дослідник Йі-Сянг Дж. Ванг у своєму дослідженні «Про підготовку молодих лікарів у Китаї» (On the training of young doctors in China) представляе деякі свої особисті погляди на суперечливу тему, як підвищити ефективність підготовки молодих лікарів у Китаї. На його думку, першим і найважливішим для якісної підготовки фахівців у галузі медицини є вступ відмінних студентів у медичні ЗВО Китаю (Ванг, 2015: 182). Студенти-медики повинні бути високоінтелектуальними й зацікавленими у вивченні медицини як в університеті, так і впродовж усього життя, оскільки медична наука постійно прогресує, розвивається і лише такий лікар буде затребуваний у суспільстві і зможе принести користь суспільству.

У медичних університетах Китаю навчальна програма для фахівців у галузі медицини є стандартизованою для різних регіонів країни. ЗВО в КНР готує майбутніх лікарів, розвиваючи їхні клінічні навички та аналітичне мислення, застосовуючи проблемне навчання під час підготовки висококваліфікованих фахівців у галузі медицини.

Йі-Сянг Дж. Ванг стверджує, що завдяки унікальним особливостям медичної освіти, порівняно з іншими програмами підготовки, такими як гуманітарними та науковими, медичним університетам корисно мати напівнезалежне або самостійне управління (Ванг, 2015: 183).

Президент Гонконзької медичної академії Дональд Лі у своєму дослідженні «Навчання лікарів первинної медичної допомоги в Китаї: Трансформація загальної практики» (Training doctors for primary care in China: Transformation of general practice education) зазначає, що Китай прагне до зміцнення послуг первинної медичної допомоги шляхом навчання та залучення кваліфікованих лікарів загальної практики. Зі старінням населення та модернізацією способу життя в Китаї відбулися великі зміни в спектрі досліджень поширених у країні захворювань, оскільки хронічні захворювання стають основною причиною підвищення рівня смертності, на відміну від інфекційних захворювань (Лі, 2016: 2). Як постійні зусилля для поліпшення якості первинної медичної допомоги в багатьох провінціях Китаю було створено навчальні центри, що відповідають міжнародним стандартам. Створений центр загальної практики в Шанхайській лікарні Чжуншань Шанхайського університету Фудань під керівництвом професора 
Чжоу Шань Чжу був акредитований Всесвітньою організацією сімейних лікарів (WONCA) як сертифікований навчальний центр із сімейної медицини, що відповідає вимогам освітнього комітету WONCA.

Важливу роль у країні відіграє Китайська асоціація лікарів (CMDA). Це національна, добровільна, неприбуткова, професійна асоціація 3 4,6 мільйона медичних працівників у Китаї, що представляє колективну позицію китайських лікарів, хірургів, медичних дослідників і медичних працівників (Китайська асоціація лікарів, 2020). Асоціація виступає за поліпшення державного медичного обслуговування та забезпечує керівництво для китайської медичної спільноти. Вона також пропонує та забезпечує міжнародні тренінги зі стандартизованого навчання лікарів-резидентів Китаю, наприклад за навчальною програмою міжнародного рівня з питань «Хронічного управління хворобами» застосовується модель електронного навчання в Університеті Фенікса (University of Phoenix) в невеликих навчальних аудиторіях. Програма підтримується Канадським товариством із питань охорони здоров'я. Це свідчить, що китайська медична освіта постійно акумулює та адаптує зарубіжний передовий досвід із підготовки лікарів у вітчизняну систему освіти.

Йі-Сянг Дж. Ванг у праці «Запровадити механізм добросовісної конкуренції в системі охорони здоров'я Китаю» (Introduce fair competition mechanism in China healthcare system) зазначає, що підвищення ефективності китайської системи охорониздоров'я $€$ ключовим для розв'язання поточних проблем, наприклад поліпшення клінічних навичок китайських лікарів, зменшення непотрібного або повторюваного лабораторного або візуального обстеження, щоб уникнути надмірного лікування, оскільки в Китаї запроваджується обов'язкова трирічна схема навчання в інтернатурі (Ванг, 2014: 499). Дослідники в КНР вивчають, чи буде ця схема набагато кращою, ніж трирічна професійна програма підготовки магістра, яка існує вже багато років.

Американський коледж лікарів грудної клітки (the American College of Chest Physicians - CHEST) розробив програму стипендій в галузі медицини, а саме - лікування легенів і критичної допомоги в Китаї(Білл, 2017).CHEST розраховуєрозповсюдити таку програму в 30-50 3ВО, очікуючи на офіційне визнання Міністерством охорони здоров'я Китаю як програми субспеціального навчання, що дозволить CHEST впровадити іiї на всій території Китаю.

Китайські вчені Сікін Ліан, Ці Чень, Мі Яо, Чунхуа Чі, Майкл Д. Феттерс у праці «Підготовка до роботи лікарем загальної практики в
Китаї» (Training Pathways to Working as a General Practitioner in China) виявили три важливих шляхи для вдосконалення підготовки фахівців у галузі медицини для загальної практики: 1) «пост трансфер» навчання для ліцензованих лікарів або помічників лікарів, щоб стати лікарем загальної практики; 2) загальна практика, що передбачає п'ятирічну бакалаврську програму та три роки резидентури, і 3) бакалаврська освіта із сімейної медицини, що готує студентів до сільської практики (Ліан та інші, 2019: 262).

Згідно 3 експериментальним дослідженням «Симуляційний навчальний курс для фахівців сімейної медицини в Китаї, які працюють із COVID-19» (A simulation training course for family medicine residents in China managing COVID-19), Д. Ши, Х. Лу, Х. Ван, С. Бао, Л. Цянь та інші очікують, що лікарі-резиденти із сімейної медицини будуть підготовлені як компетентні фахівці з якомога більшою кількістю оновлених знань, що дасть їм змогу ефективно розв'язувати реальні клінічні проблеми під час роботи з високо інфекційними захворюваннями (Ши, Лу, Ван та інші, 2020: 366). Такі добре розроблені програми підготовки лікарів в університетах Китаю є доступними та якісними, вони передбачають підготовку в реальних ситуаціях або штучно створених, подібних до тих, які можуть трапитися в професійної діяльності. Моделювання дає викладачу змогу модулювати або контролювати ступінь складності та небезпеки, оцінюючи індивідуальну та командну участь студентів. Такі види навчання майбутніх лікарів передбачають як безпеку пацієнтів, так і самозахист студентів-медиків. Для досягнення цієї мети викладач повинен навчити студентів обмежувати свої рішення, чітко дотримуватися правил протоколу. Сценарій моделювання ситуацій допомагає слухачам взаємодіяти в реальних ситуаціях; таке навчання також дуже доповнює традиційне дидактичне навчання.

Висновки. Підсумовуючи зазначене вище, можемо констатувати, що в Китаї триває процес постійного вдосконалення фахової освіти лікарів. Китайський уряд розпочав амбіційну нову місію $з$ підготовки висококваліфікованих фахівців у галузі медицини. Зміни в навчанні стосуються підготовки лікарів загальної практики, які мають оволодіти професійними компетентностями, їхня кваліфікація має відповідати міжнародним стандартним кваліфікаційним наборам лікарських навичок. У КНР відбулися значні зміни в якості підготовки фахівців у галузі медицини за останні десятиліття. За результатами системного аналізу наукової літератури визначено проблеми, що 
потребують дослідження, а саме: тенденції, зміст, форми, методи й особливості підготовки висо- кокваліфікованих компетентних фахівців у галузі медицини в університетах Китаю.

\section{СПИСОК ВИКОРИСТАНИХ ДЖЕРЕЛ}

1. Beall A. Association Sets Training Standards for Chinese Lung Doctors. The Center for Association Leadership. ASAE. 2017. URL: https://www.asaecenter.org/resources/articles/an_magazine/2017/january-febr uary/association-sets-training-standards-for-chinese-lung-doctors.

2. Chinese Medical Doctor Association. Home of Four Million Medical Doctors in China. URL: http://www.cmdae.org.

3. Li D. Training doctors for primary care in China: Transformation of general practice education. Journal of Family Medicine and Primary Care. 2016. Vol. 5. Issue 1. P. 1-2. URL: https://www.ncbi.nlm.nih.gov/pmc/articles/PMC4943113. DOI: $10.4103 / 2249-4863.184614$.

4. Lian S., Chen Q., Yao M., Chi C., Fetters M. D. Training Pathways to Working as a General Practitioner in China. Family Medicine. 2019. Vol. 51. Issue 3. P. 262-270. URL: https://journals.stfm.org/familymedicine/2019/march/fetters-2018-0101. DOI: 10.22454/FamMed.2019.329090.

5. Shi D., Lu H., Wang H., Bao S., Qian L., Dong X., Tao K., Xu Z. A simulation training course for family medicine residents in China managing COVID-19. Australian Journal of General Practice. 2020. Vol. 49. Issue 6. P. 364-368. URL: https://www1.racgp.org.au/ajgp/2020/june/test. DOI: 10.31128/AJGP-04-20-5337.

6. The World Bank. Data. Physicians (per 1,000 people). 2014. URL: http://data.worldbank.org/indicator/SH.MED. PHYS.ZS.

7. Wang J. Yi-X. Introduce fair competition mechanism in China healthcare system. Quantitative Imaging in Medicine and Surgery. 2014. Vol. 4. Issue 6. P. 498-499. URL: https://www.ncbi.nlm.nih.gov/pmc/articles/PMC4256236. DOI: 10.3978/ j.issn.2223-4292.2014.11.14.

8. Wang J. Yi-X. On the training of young doctors in China. Quantitative Imaging in Medicine and Surgery. 2015. Vol. 5. Issue 1. P. 182-185. URL: https://www.ncbi.nlm.nih.gov/pmc/articles/PMC4312294. DOI: 10.3978/j.issn.2223-4292. 2014.12.01.

\section{REFERENCES}

1. Beall A. Association Sets Training Standards for Chinese Lung Doctors. The Center for Association Leadership. ASAE. 2017. URL: https://www.asaecenter.org/resources/articles/an_magazine/2017/january-febr uary/association-sets-training-standards-for-chinese-lung-doctors [in English].

2. Chinese Medical Doctor Association. Home of Four Million Medical Doctors in China. URL: http://www.cmdae.org/ [in English].

3. Li D. Training doctors for primary care in China: Transformation of general practice education. Journal of Family Medicine and Primary Care. 2016. Vol. 5. Issue 1. P. 1-2. URL: https://www.ncbi.nlm.nih.gov/pmc/articles/PMC4943113. DOI: 10.4103/2249-4863.184614 [in English].

4. Lian S., Chen Q., Yao M., Chi C., Fetters M. D., Training Pathways to Working as a General Practitioner in China. Family Medicine. 2019. Vol. 51. Issue 3. P. 262-270. URL: https://journals.stfm.org/familymedicine/ 2019/march/fetters-2018-0101. DOI: 10.22454/FamMed.2019.329090 [in English].

5. Shi D., Lu H., Wang H., Bao S., Qian L., Dong X., Tao K., Xu Z. A simulation training course for family medicine residents in China managing COVID-19. Australian Journal of General Practice. 2020. Vol. 49. Issue 6. P. 364-368. URL: https://www1.racgp.org.au/ajgp/2020/june/test. DOI: 10.31128/AJGP-04-20-5337 [in English].

6. The World Bank. Data. Physicians (per 1,000 people). 2014. URL: http://data.worldbank.org/indicator/SH.MED. PHYS.ZS [in English].

7. Wang J. Yi-X. Introduce fair competition mechanism in China healthcare system. Quantitative Imaging in Medicine and Surgery. 2014. Vol. 4. Issue 6. P. 498-499. URL: https://www.ncbi.nlm.nih.gov/pmc/articles/PMC4256236. DOI: 10.3978/j.issn.2223-4292.2014.11.14 [in English].

8. Wang J. Yi-X. On the training of young doctors in China. Quantitative Imaging in Medicine and Surgery. 2015. Vol. 5. Issue 1. P. 182-185. URL: https://www.ncbi.nlm.nih.gov/pmc/articles/PMC4312294. DOI: 10.3978/j.issn.2223-4292. 2014.12.01 [in English]. 